\title{
ORAL ADMINISTRATION OF PHENOXYMETHYL PENICILLIN (DISTAQUAINE V)
}

\author{
By L. Henry, M.B., Ch.B., M.R.C.S., L.R.C.P. \\ Senior House Officer \\ and M. J. Meynell, M.D., M.R.C.P., D.P.H. \\ Clinical Pathologist
}

From the Department of Clinical Pathology, The General Hospital, Birmingham

The oral administration of penicillin has many advantages, and a number of reports have been published on various preparations. In all of these absorption was found to be very irregular, large dosage being required to maintain satisfactory blood levels. (Wright et al., I953; Fairbrother and Daber, 1954; Cathie and MacFarlane, 1953; Doxiadis et al,. I95I.) In order to provide more reliable absorption, Phenoxymethyl Penicillin ('Distaquaine $V^{\prime}$ ) has recently been introduced in this country. Although it has been in use on the Continent (Brandl et al., 1953), no reports have yet appeared in the English literature. This paper gives the results of a limited survey of serum penicillin levels after the oral administration of 'Distaquaine $V$ ' to three patients and 12 normal subjects whose ages ranged from $18-47$ years.

\section{Method}

The tablets contain $60 \mathrm{mg}$. 'Distaquaine V' (approx. 100,000 units) and each subject had blood estimations performed after the ingestion of 1,2 and 4 tablets. The dose was given well before the mid-day meal and blood was withdrawn at hourly intervals, the serum being separated as soon as possible and the titration carried out on the same day. The serum penicillin levels were estimated by a serial dilution method using Glucose Andrade peptone water inoculated with one drop of an overnight broth culture of the Oxford strain of Staphylococcus aureus (sensitive to 0.02 units of penicillin per c.c.). Readings were taken after incubation for 18 hours at $37^{\circ} \mathrm{C}$. and the end point was based on colour change and visible growth, both being compared with a control of normal serum containing a known amount of penicillin.

In some instances it was found necessary to subculture on to a solid medium to ascertain the end-point.

\section{Results}

The serum penicillin levels obtained are shown in Tables $\mathrm{I}-3$ and Figs. $\mathrm{I}-3$. Fig. 4 is a graph of the average levels for all three doses.

\begin{tabular}{lclll}
\hline SubJECT & \multicolumn{3}{l}{ Hours } & \\
& I & 2 & 3 & 4 \\
\hline G.W. & .16 & .08 & .08 & .04 \\
A.L. & .08 & .08 & .08 & .04 \\
M.J.M. & .08 & .08 & .04 & .04 \\
L.H. & .16 & .08 & .04 & .04 \\
M.A.B. & .32 & .08 & .04 & .04 \\
A.C.A. & .16 & .08 & .04 & .04 \\
E.T. & .64 & .04 & - & - \\
A.R.T. & .16 & .08 & .04 & - \\
A.E.J. & .32 & .08 & .04 & - \\
P.J.D. & I.28 & .16 & .04 & - \\
A.T. & .16 & .08 & .08 & .08 \\
N.C.B. & .04 & .08 & .16 & .16
\end{tabular}

Average

$\begin{array}{lllll}\text { LEVELS } & .3 & .08 & .06 & .04\end{array}$

Table I. Serum Penicillin levels (units/c.c.) in 12 normal subjects after administration of 100,000 units of Distaquaine V.

\begin{tabular}{|c|c|c|c|c|c|c|}
\hline \multirow[t]{2}{*}{ Subject } & \multicolumn{6}{|c|}{ Hours } \\
\hline & $\mathbf{I}$ & 2 & 3 & 4 & 5 & 6 \\
\hline G.W. & .64 & .16 & .04 & .04 & .04 & - \\
\hline A.L. & .32 & .16 & .08 & .08 & .08 & .04 \\
\hline M.J.M. & .64 & .32 & .08 & .04 & - & - \\
\hline L.H. & .64 & .16 & .08 & .04 & - & 一 \\
\hline M.A.B. & .64 & .32 & .08 & .04 & 一 & 一 \\
\hline A.C.A. & .64 & .32 & .08 & .04 & - & - \\
\hline E.T. & $2 \cdot 5^{6}$ & .16 & .04 & - & - & - \\
\hline A.R.T. & .64 & .16 & .08 & - & - & - \\
\hline A.E.J. & .16 & .64 & .32 & .16 & - & - \\
\hline D. & I . 28 & $\cdot 32$ & .08 & - & - & - \\
\hline A.T. & .16 & $\cdot 32$ & .16 & .08 & - & - \\
\hline & .04 & .64 & .16 & .08 & - & - \\
\hline
\end{tabular}

Average

\begin{tabular}{lllllll} 
LEVELS & .75 & .3 & .1 & .05 & .01 & - \\
\hline
\end{tabular}

Table 2. Serum Penicillin levels (units/c.c.) in 12 normal subjects after administration of 200,000 units of Distaquaine $\mathrm{V}$. 


\begin{tabular}{|c|c|c|c|c|c|c|}
\hline \multirow[t]{2}{*}{ Subject } & \multicolumn{6}{|c|}{ Hours } \\
\hline & I & 2 & 3 & 4 & 5 & 6 \\
\hline G.W. & I. 28 & I. 28 & 1.28 & .32 & .08 & .04 \\
\hline A.L. & 2.56 & .64 & .32 & .08 & .04 & - \\
\hline M.J.M. & I. 28 & 1.28 & .32 & .08 & - & 一 \\
\hline L.H. & 1.28 & .32 & .16 & .08 & - & - \\
\hline M.A.B. & 2.56 & .64 & .32 & .08 & - & 一 \\
\hline A.C.A. & 2.56 & 1.28 & .32 & .16 & 一 & - \\
\hline E.T. & 5.12 & .64 & .16 & .04 & 一 & - \\
\hline A.R.T. & 2.56 & & & .08 & .04 & - \\
\hline A.E.J. & - & 2.56 & I. 28 & .64 & .16 & .08 \\
\hline P.J.D. & 5.12 & 1.28 & .16 & .04 & - & - \\
\hline A.T. & .64 & 1.28 & .64 & .16 & .08 & .04 \\
\hline N.C.B. & .32 & I. 28 & .64 & .64 & .32 & .16 \\
\hline
\end{tabular}

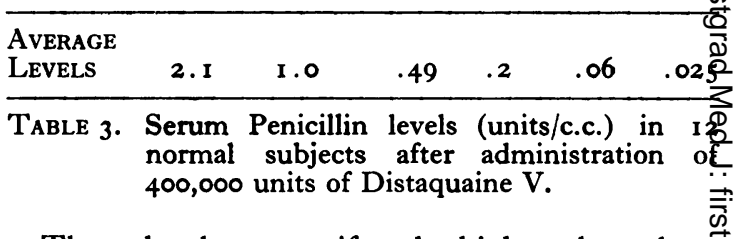

These levels are uniformly higher than those obtained with other preparations of penicillin, but even so, extreme individual variation was stils encountered. This can be seen from Table $\mathbb{D}$ where, one hour after a dose of 4 tablets, levels ranged from nil to 5.12 units per c.c. Individual variation was also noted, and in the case of one

FIG. I

FIG. 2

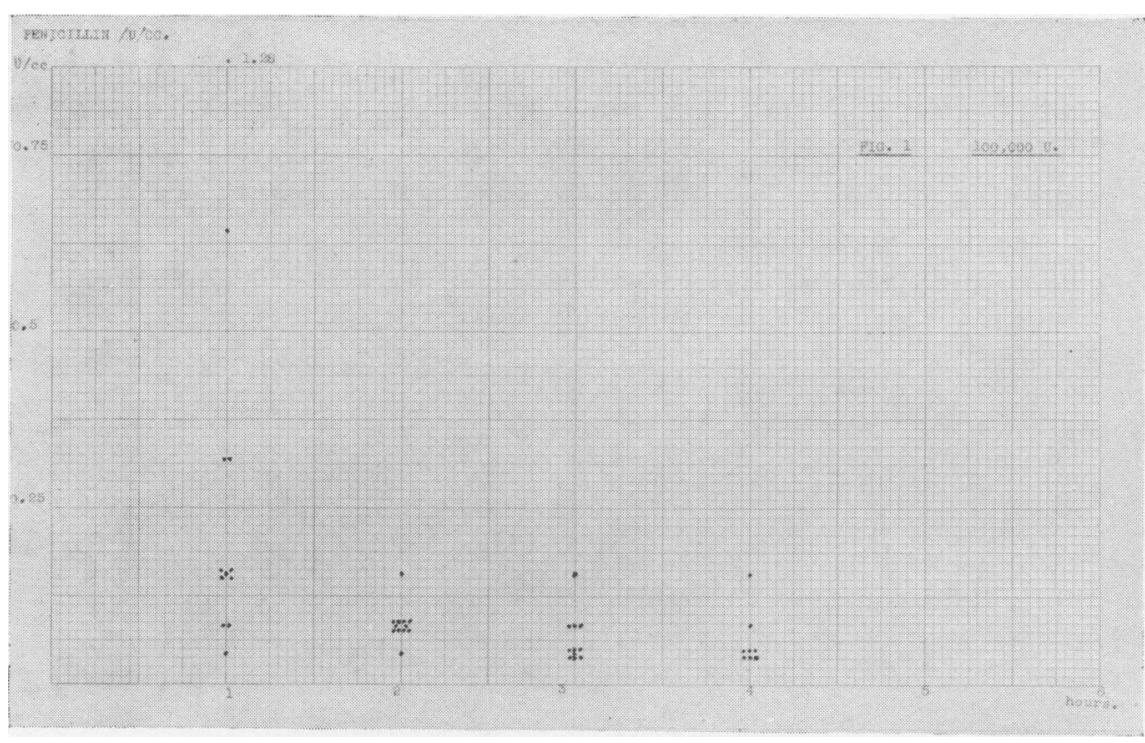




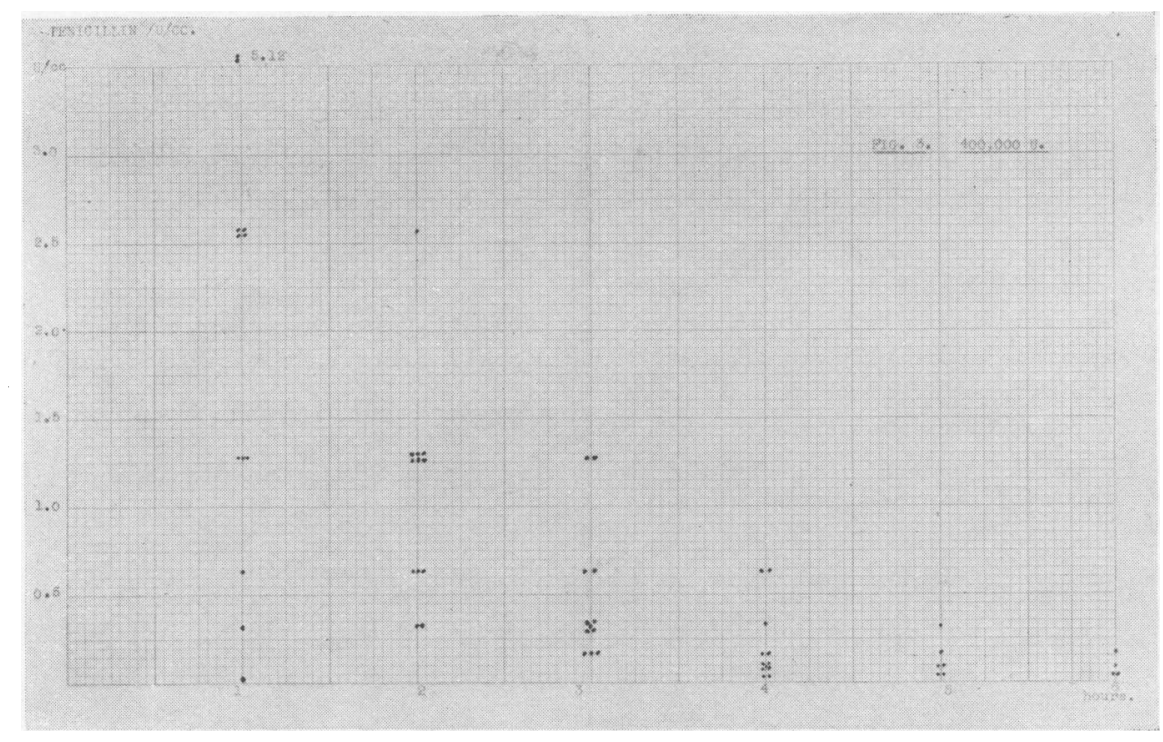

FIG. 3

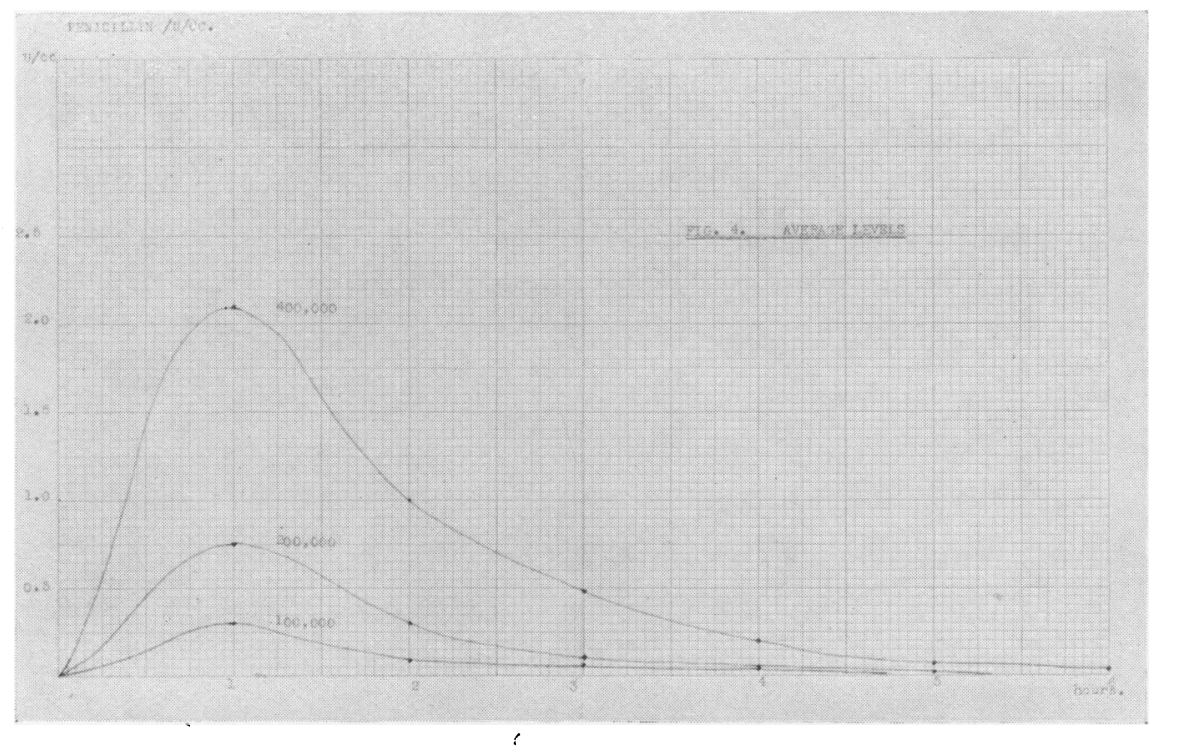

Fig. 4

subject (A.E.J.), the peak level was progressively delayed, the I-hour levels decreasing as the dose was increased. However, in view of the levels obtained and their duration, it was felt that the preparation was satisfactory for clinical use. In order to demonstrate any cumulative effect, daily estimations were performed on three patients receiving 2 tablets 6 -hourly. Each day for three days blood was taken immediately before the midday dose and again at I.O p.m. The results are shown in Table 4 and probably represent individual variation rather than a cumulative effect.

\begin{tabular}{|c|c|c|c|c|c|c|}
\hline & \multicolumn{2}{|c|}{ Ist Day. } & \multicolumn{2}{|c|}{ 2nd Day. } & \multicolumn{2}{|c|}{ 3rd Day. } \\
\hline Patient & $\begin{array}{l}12.0 \\
\text { noon }\end{array}$ & $\begin{array}{l}\text { r.o. } \\
\text { p.m. }\end{array}$ & $\begin{array}{l}12.0 \\
\text { noon }\end{array}$ & $\begin{array}{l}\text { I.o } \\
\text { p.m. }\end{array}$ & $\begin{array}{l}12.0 \\
\text { noon }\end{array}$ & $\begin{array}{l}\text { I.O } \\
\text { p.m. }\end{array}$ \\
\hline $\begin{array}{l}1 . \\
2 . \\
3 .\end{array}$ & $\begin{array}{r}.08 \\
.08 \\
\text { Nil }\end{array}$ & $\begin{array}{l}.64 \\
.32 \\
.64\end{array}$ & $\begin{array}{l}\text { Nil } \\
\text {.०4 } \\
\text { Nil }\end{array}$ & $\begin{array}{r}.32 \\
1.28 \\
0.64\end{array}$ & $\begin{array}{l}\text { Nil } \\
\dot{0} 04 \\
\text { Nil }\end{array}$ & $\begin{array}{r}.64 \\
1.28 \\
1.28\end{array}$ \\
\hline
\end{tabular}

TARLE 4. Serum Penicillin levels (units/c.c.) in patients receiving 200,000 units Distaquaine $V 6$ hourly. Estimations performed before the midday dose and I hour later. 


\section{Side Effects}

Three of the normal subjects experienced mild abdominal discomfort and borborygmi, but there was no nausea, vomiting or diarrhoea.

\section{Summary}

Serum penicillin levels were estimated on 12 normal subjects using varying dosage of 'Distaquaine $V^{\prime}$.

The levels obtained and their duration were considered satisfactory, although considerable individual variation was still encountered.

In three patients receiving treatment with 'Distaquaine V' no cumulative effect was noted.
We wish to thank Miss M. A. Butcher for technical assistance, Miss M. N. Ellis for typing this report, and the twelve 'volunteers' from the Laboratory.

This work was carried out with the help of $a_{c}$ grant from the Endowment Research Fund of the United Birmingham Hospitals.

\section{BIBLIOGRAPHY}

BRANDL, E. et al. (1953), Wien. Med. Wchnschr., 103, 602-7.

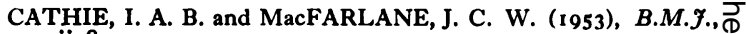
ii, 805 .

DOXIADIS, S. A. et al. (195I), B.M.F., i, 16

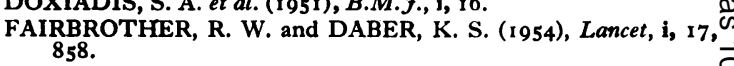

WRIGHT, S. S. et al. (1953), Fournal of Laboratory and Clinical ${ }^{\circ}$ Medicine, 42, 3, 417 .

\title{
CARDIAC DISEASE
}

(Postgraduate Medical Journal)

Price 3s. 10d. post free

INTRODUCTION

Walter Somerville, M.D., M.R.C.P.

ANGIOGRAPHY

J. Norman Pattinson, M.B., B.Chir., D.M.R.D.,

F.F.R.

BEDSIDE DIAGNOSIS OF CONGENITAL HEART DISEASE

Walter Somerville, M.D., M.R.C.P.

SURGICAL TREATMENT OF CONGENITAL HEART DISEASE

W. P. Cleland, M.R.C.P., F.R.C.S.

PREGNANCY AND RHEUMATIC HEART DISEASE

Samuel Oram, M.D., F.R.C.P.
DRUG TREATMENT OF HYPERTENSION

E. G. McQueen, M.B., M.R.C.P., and F. H. Smirk, M.D., F.R.C.P.

TREATMENT OF BACTERIAL ENDOCARDITIS

Ian G. W. Hill, C.B.E., T.D., F.R.C.P.E., M.R.C.P., F.R.S.E.

THE MANAGEMENT OF COR PULMONALE J. F. Goodwin, M.D., M.R.C.P.

THE CARDIAC RISK IN ANAESTHESIA AND SURGERY

Graham W. Hayward, M.D., F.R.C.P.

Published by

THE FELLOWSHIP OF POSTGRADUATE MEDICINE

60, Portland Place, London, W.1

\section{HOW TO GET THERE}

An Address Book for the Medical profession, showing how to reach the various Colleges, Societies, Institutes and Hospitals in or near London

New (Fourth) Edition: 1954

\author{
Published by the \\ FELLOWSHIP OF POSTGRADUATE MEDICINE \\ 60 Portland Place, London, W.I
}

Price 2s. 6d. (2s. 10d., post free) 